\title{
PENGGUNAAN BEBERAN CHARTA UNTK MENINGKATKAN MOTIVASI BELAJAR SISWA PADA MATA PELAJARAN IPA
}

\author{
ENDANG WAHYUNINGSIH \\ SMPN 2 Baureno Bojonegoro \\ Email : endangipa@gmail.com
}

\begin{abstract}
ABSTRAK
Penelitian ini bertujuan untuk meningkatkan motivasi belajar siswa melalui penggunaan beberan charta dalam pembelajaran pada siswa SMP. Subyek penelitian adalah 26 siswa kelas VIII-C SMPN 2 Baureno Bojonegoro. Pada umumnya siswa dalam belajar hanya membaca tanpa memahami isi pelajaran. Mereka kurang terlatih untuk berfikir, menyampaikan ide dan memecahkan masalah. Pada setiap kegiatan pembelajaran IPA siswa cenderung pasif, kurang bersemangat dan sulit untuk aktif bertanya maupun menyampaikan pendapatnya serta kurang bertanggung jawab terhadap tugasnya. Dalam pembelajaran tampak motivasi siswa saat belajar IPA masih rendah. Penelitian ini dilaksanakan dengan rancangan penelitian tindakan kelas yang prosedur pelaksanaannya mengikuti prinsip dasar penelitian tindakan yang umum. Prosedur tersebut merupakan suatu proses siklus atau daur ulang, yang dimulai dari tahap perencanaan, tahap pelaksanaan tindakan, tahap observasi/evaluasi, dan tahap refleksi. Pelaksanaan penelitian ini dilakukan sebanyak dua siklus. Hasil penelitian menunjukkan adanya peningkatan dari siklus pertama ke siklus kedua. Berdasarkan data hasil penelitian pada siklus pertama dan siklus kedua, semua indikator mengalami peningkatan keberhasilan sesuai dengan yang diharapkan.
\end{abstract}

\author{
Info Artikel : \\ Diterima : \\ 7 Juni 2021 \\ Diperbaiki : \\ 14 Juni 2021 \\ Disetujui : \\ 2 Juli 2021
}

\section{Kata Kunci: \\ Motivasi, \\ Beberan Charta, Siswa SMP}

\section{PENDAHULUAN}

Pembelajaran adalah proses belajar mengajar yang terdiri atas komponen-komponen belajar. Ada pengajar, ada siswa yang belajar, ada materi yang disampaikan, menggunakan metode tertentu dan juga strategi pengajaran yang tepat. Menurut Peter Kline dalam Angkowo dan Kosasih (2007. 49), belajar akan efektif jika dilakukan dalam suasana menyenangkan (fun and enjoy). Maka perlu diciptakan suasana dan sistem (kondisi) belajar yang kondusif, disamping faktor lain yang akan menentukan hasil belajar siswa. Salah satu faktor yang mempengaruhi adalah faktor pengajar. Oleh sebab itu, mengajar yang diartikan sebagai suatu usaha menciptakan sistem lingkungan, harus memungkinkan terjadinya proses pembelajaran yang fun and enjoy. Tetapi perlu diketahui pula bahwa sistem lingkungan ini pun dipengaruhi oleh berbagai komponen yang saling berinteraksi, antara lain, tujuan pembelajaran, bahan kajian yang disampaikan, guru, siswa, jenis kegiatan yang dikembangkan, metode serta media pembelajaran yang dipilih.

Dengan metode dan media yang tepat diharapkan seorang pengajar mampu memotivasi siswa untuk belajar secara aktif, giat, mandiri dan cerdas sehingga mendapatkan hasil belajar yang maksimal. Selain itu juga dengan metode dan strategi yang tepat seorang pengajar bisa menciptkan suasana belajar yang tidak membosankan, tetapi justru akan menjadi sebuah kegiatan yang sangat menyenangkan dan berhasil guna.

Berdasarkan pengalaman guru selama mengajar di kelas VIII-C SMPN 2 Baureno Bojonegoro, pada umumnya siswa dalam belajar hanya membaca tanpa memahami isi pelajaran. Mereka kurang terlatih untuk berfikir, menyampaikan ide dan memecahkan masalah. Pada setiap kegiatan pembelajaran IPA siswa cenderung pasif, kurang bersemangat dan sulit untuk aktif bertanya maupun menyampaikan pendapatnya serta kurang bisa bertanggungjawab terhadap tugasnya. Dalam kegiatan pembelajaran sering tampak motivasi siswa saat belajar IPA masih rendah. Hal ini bisa dilihat dari pengamatan terhadap proses pembelajaran sehari-hari, 
hanya $15 \%$ siswa aktif bertanya atau menyampaikan pendapatnya saat kegiatan pembelajaran. sedangkan $85 \%$ siswa pasif, hanya mendengarkan dan menulis apa yang disampaikan oleh guru. Bahkan ketika siswa diminta oleh guru untuk mempresentasikan hasil pekerjaannya hanya $23 \%$ siswa yang mampu dan berani mengkomunikasikan hasil pekerjaannya.

Berdasarkan permasalahan tersebut, guru yang selanjutnya berperan sebagai peneliti bersama dengan guru IPA yang lain melakukan diskusi secara mendalam terhadap proses pembelajaran IPA yang selama ini dilakukan di kelas VIII-C SMPN 2 Baureno Bojonegoro. Hasil diskusi kami meyimpulkan bahwa siswa kelas VIII-C SMPN 2 Baureno Bojonegoro kurang termotivasi dalam belajar IPA sehingga pemahaman terhadap materi juga rendah. Hal ini bisa dilihat dari nilai siswa yang masih rendah, masih berada dibawah KKM yang ditetapkan sekolah yaitu 65 . Hanya $38,46 \%$ dari siswa yang nilai ulangannya bisa mencapai KKM yang diharapkan.

Untuk memecahkan kesulitan tersebut, guru mencoba mencari strategi baru dalam pembelajaran yang melibatkan siswa secara aktif, merancang kegiatan pembelajaran yang mampu mengembangkan berbagai kompetensi, baik dalam ranah kognitif, ranah afektif maupun ranah psikomotorik siswa. Salah satu alternatifnya adalah dengan menggunakan media pembelajaran. Penggunaan media dipilih karena dengan media diharapkan akan mampu memotivasi siswa untuk belajar aktif dan memudahkan siswa dalam memahami materi pembelajaran.

Menurut Assosiasi Pendidikan Nasional (National Education Assosiation/NEA), media merupakan benda yang dimanipulasikan dilihat, didengar, dibaca atau dibicarakan beserta instrumen yang dipergunakan dengan baik dalam kegiatan pembelajaran, dapat mempengaruhi efektifitas program intruksional (Sabri, 2005.112) Dari uraian tersebut dapat disimpulkan bahwa media adalah segala sesuatu yang dapat menyalurkan pesan, yang dapat merangsang pikiran, perasaan dan kemauan siswa sehingga mendorong terjadinya proses belajar pada dirinya.

Media pembelajaran yang di gunakan peneliti di sini adalah media yang mudah didapat, mudah dibuat dan murah tetapi diharapkan mampu memotivasi belajar siswa dan mampu menciptakan suasana belajar di kelas meriah, aktif, senang, belajar lebih mandiri, efektif dan efisien, yang selanjutnya diharapkan juga akan mampu meningkatkan pemahaman siswa dalam belajar IPA, yaitu dengan menggunakan media charta. Selama ini pemakaian charta hanya di pajang di depan saat guru menjelaskan materi pelajaran sehingga kurang bisa mengaktifkan siswa. Untuk itu peneliti mencoba mengkombinasikan media charta yang dilengkapi kartukartu yang berisi dengan pokok materi belajar, yaitu dengan membuat Charta yang digunakan sebagai beberan dalam kegiatan pembelajaran. Karena metode ini belum pernah dilakukan di sekolah kami, maka peneliti mencoba untuk menerapkannya yang sekaligus dijadikan sebagai Penelitian Tindakan Kelas dengan harapan dapat meningkatkan motivasi belajar siswa.

Motivasi belajar adalah kondisi psikis yang mendorong seseorang untuk melakukan sesuatu, yang berarti pula mendorong seseorang untuk belajar. Motivasi juga berarti keseluruhan prestasi atau daya penggerak dalam diri individu yang menimbulkan kegiatan belajar dan menjamin kelangsungan belajar(Winkel,1984: 45). Dengan adanya motivasi, siswa akan senantiasa semangat untuk terus belajar tanpa adanya paksaan dari pihak manapun. Untuk menumbuhkannya tentunya bukaan perkara mudah karena setiap siswa memiliki karakter dan keinnginan yang berbeda-beda. Perkara ini memang tidak sepenuhnya menjadi tanggung jawab guru, namun kita sebagai seorang guru memegang peranan penting di dalamnya.Lagipula sering kali para siswa belum memahami untuk apa ia belajar hal-hal yang diberikan oleh sekolah. Karena itu motivasi terhadap pelajaran perlu dibangkitkan oleh guru sehingga para siswa mau dan ingin belajar. Usaha yang dapat dikerjakan oleh guru memang banyak, dan karena itu di dalam memotivasi siswa kita tidak akan menentukan suatu formula tertentu yang dapat digunakan setiap saat oleh guru. 


\section{METODE PENELITIAN}

Penelitian ini dilaksanakan dengan rancangan penelitian tindakan kelas yang prosedur pelaksanaannya mengikuti prinsip dasar penelitian tindakan yang umum. Prosedur tersebut merupakan suatu proses siklus atau daur ulang, yang dimulai dari tahap perencanaan, tahap pelaksanaan tindakan, tahap observasi/evaluasi, dan tahap refleksi. Pelaksanaan penelitian ini sebanyak dua siklus. Siklus pertama dilaksanakan dalam 2 kali kegiatan pembelajaran dan siklus kedua 2 kali kegiatan pembelajaran. Kegiatan perencanaan diawali dengan mengembangkan silabus, menyusun RPP, menyusun media yang akan digunakan dan menyusun instrumen pengamatan. Adapun instrumen penelitian yang harus disiapkan antara lain: (1) Lembar observasi tentang tindakan guru ; (2) Lembar observasi motivasi/keaktifan siswa ; (3) Lembar penilaian atau rubrik penilaian hasil belajar siswa; (4) Angket siswa ; (5) Dokumentasi (Memperjelas peroleh data).

Indikator keberhasilan tindakan yang dilakukan guru selama penelitian dengan penggunaan media charta dalam pembelajaran ini adalah jika $100 \%$ siswa dalam kelas aktif mengikuti kegiatan pembelajaran (aktif bertanya, aktif menjawab pertanyaan atau menanggapi pernyataan teman) dan sekurang-kurangnya $75 \%$ dari siswa mendapatkan nilai sesuai dengan KKM yang ditetapkan sekolah yaitu 65. Adapun pengumpulan data dilakukan pada setiap siklus dimulai dari awal sampai akhir tindakan siklus I sampai II. Pengumpulan data dilakukan dengan menggunakan beberapa instrumen yang sudah disiapkan.

Sumber data dalam penelitian ini adalah siswa SMPN 2 Baureno kelas $8 \mathrm{C}$ yang berjumlah 26 siswa. Sedangkan analisis data dilakukan dengan mendiskripsikan data dari hasil pengamatan dan angket menjadi data kualitatif. Data tersebut meliputi 4 hal, yaitu data hasil pengamatan tentang kemampuan guru memanfaatkan media dalam pengajaran, aktifitas/motivasi siswa, data hasil penilaian belajar siswa terhadap materi pembelajaran, dan data tentang respon siswa terhadap kegiatan pembelajaran. Analisis data dilakukan secara simultan, sejak dilaksanakannya siklus I sampai terakhir.

\section{HASIL DAN PEMBAHASAN}

\section{Hasil}

\section{Hasil Observasi Kemampuan Guru dalam PBM}

Observasi dilakukan oleh rekan guru IPA yang lain yang dalam penelitian ini berperan sebagai pengamat, dengan menggunakan lembar observasi terhadap guru dalam PBM selama 2 siklus. Adapun data hasil observasi adalah sebagai berikut:

Tabel 1. Skor Kemampuan Guru dalam PBM

\begin{tabular}{clcc}
\hline \multirow{2}{*}{ No } & \multicolumn{2}{c}{ Aspek yang diamati } & \multicolumn{2}{c}{ Skor pengamatan setiap siklus } \\
& & Siklus I & Siklus II \\
\hline 1 & Pendahuluan & 3,50 & 4,00 \\
2 & Kegiatan Inti & 3,75 & 4,25 \\
3 & Penutup & 2,70 & 4.00 \\
4 & Keadaan Kelas & 2,75 & 3,75 \\
& & & 4.00 \\
\hline
\end{tabular}

\section{Hasil Observasi Aktivitas Siswa dalam PBM}

Hasil observasi diperoleh dengan menggunakan lembar observasi yang dilakukan oleh peneliti dan juga anggota tim lainnya terhadap aktivitas siswa dalam PBM selama 2 siklus. Data hasil observasi tertera dalam tabel berikut: 
Tabel 2. Hasil Pengamatan / Observasi Aktivitas Siswa Dalam Pembelajaran

\begin{tabular}{|c|c|c|c|c|c|}
\hline \multirow{3}{*}{ No. } & \multirow{3}{*}{$\begin{array}{c}\text { Aspek yang } \\
\text { diamati }\end{array}$} & \multicolumn{4}{|c|}{ Presentase aktivitas siswa setiap siklus } \\
\hline & & \multicolumn{2}{|c|}{ Siklus I ( \%) } & \multicolumn{2}{|c|}{ Siklus II (\%) } \\
\hline & & Jumlah & $\%$ & Jumlah & $\%$ \\
\hline 1. & $\begin{array}{l}\text { Memperhatikan } \\
\text { penjelasan guru }\end{array}$ & 15 & 57.69 & 24 & 92.30 \\
\hline 2. & $\begin{array}{l}\text { Menyampaikan } \\
\text { jawaban/tanggapan }\end{array}$ & 16 & 61.53 & 26 & 100 \\
\hline 3. & $\begin{array}{l}\text { Merangkum materi } \\
\text { pelajaran }\end{array}$ & 15 & 57.69 & 20 & 76.92 \\
\hline 4. & $\begin{array}{l}\text { Perilaku yang tidak } \\
\text { relevan }\end{array}$ & 5 & 19.23 & 1 & 3.84 \\
\hline
\end{tabular}

3. Hasil Belajar Siswa Tentang Pemahaman dan Penguasaan Konsep

Hasil belajar siswa tentang pemahaman dan penguasaan konsep yang diperoleh dari tes setiap siklusnya dapat dilihat pada tabel berikut:

Tabel 3. Hasil Belajar Siswa Tiap Siklus

\begin{tabular}{llcc}
\hline \multirow{2}{*}{ No } & & \multicolumn{2}{c}{ Ketuntasan } \\
& & Tuntas $(\%)$ & Tidak tuntas $(\%)$ \\
\hline 1 & Siklus I & 61.54 & 38.46 \\
2 & Siklus II & 80.77 & 19.23 \\
\hline
\end{tabular}

\section{Respon Siswa Terhadap Kegiatan Belajar Mengajar}

Data ini dikumpulkan dengan menyebarkan angket kepada siswa. Hasilnya seperti yang tertera pada tabel berikut:

\begin{tabular}{ccccc}
\multicolumn{2}{c}{ Tabel } & 4. Data Persentase Respon Siswa Terhadap Kegiatan Pembelajaran \\
\hline NO & \multicolumn{1}{c}{ RESPON SISWA } & \multicolumn{2}{c}{ SIKLUS I } & \multicolumn{2}{c}{ SIKLUS II } \\
& Jumlah & Prosentase & Jumlah & Prosentase \\
\hline 1. $\quad \begin{array}{l}\text { Siswa yang menyatakan bahwa } \\
\text { media pembelajaran yang } \\
\text { diterapkan baru }\end{array}$ & 26 & $100 \%$ & 12 & $46.15 \%$ \\
2. $\begin{array}{l}\text { Siswa yang menyatakan media } \\
\text { pembelajaran menyenangkan }\end{array}$ & 24 & $92.30 \%$ & 25 & $96.15 \%$ \\
$\quad \begin{array}{l}\text { Siswa yang menyatakan bahwa } \\
\text { dengan media pembelajaran ini } \\
\text { materi lebih mudah dipahami }\end{array}$ & 26 & $100 \%$ & 24 & $92.30 \%$ \\
$\begin{array}{l}\text { Siswa yang menyatakan bahwa } \\
\text { dengan media pembelajaran ini }\end{array}$ & 32 & $100 \%$ & 24 & $92.30-\%$
\end{tabular}


guru bisa menjadi mediator dan fasilitator.

5. Siswa yang menyatakan media pembelajaran ini perlu dilanjutkan

Siswa yang menyatakan dengan media pembelajaran ini menjadi

6. lebih aktif/bersemangat dalam

$92.30 \%$

24

$92.30 \%$ mengikuti kegiatan belajar.

\section{Pembahasan}

\section{Hasil Observasi Kemampuan Guru dalam PBM}

Berdasarkan tabel 1 tentang perolehan skor kemampuan guru dalam PBM menunjukkan bahwa dari 4 aspek yang diamati, yaitu pendahuluan, kegiatan inti, penutup dan penguasaan guru terhadap kelas mengalami peningkatan dari siklus I ke siklus II. Hal ini menunjukkan juga bahwa guru telah melakukan pengajaran sesuai dengan sintak-sintak yang direncanakan. Guru juga berusaha untuk melakukan perbaikan dalam pengajarannya. Pada siklus I guru masih agak kesulitan dalam membimbing siswa yang belum terbiasa dengan penggunaan media pembelajaran ini. Guru juga kurang maksimal dalam mengelola kelas maupun waktu belajar, sehingga suasana belajar kurang kondusif dan tidak efektif. Tetapi pada siklus II guru melakukan perbaikan, baik dalam pembimbingan maupun dalam pengaturan kelompok. Pembimbingan dilakukan lebih intensif dan jumlah kelompok diperbanyak dari 2 kelompok menjadi 4 kelompok belajar, sehingga anggota tiap kelompok lebih sedikit. Akhirnya dengan perubahan tersebut mampu menciptakan suasana belajar yang lebih kondusif, efektif dan menyenangkan. Siswa lebih nyaman dalam belajar karena tidak terlalu ramai dalam kelompok belajarnya.

Dalam hal ini kami perlu melakukan pengamatan terhadap guru saat PBM karena menurut kami guru juga mempunyai peran besar dalam keberhasilan belajar siswa, selain dipengaruhi oleh faktor dari dalam siswa itu sendiri. Menurut Musfiqon (2012: 9), faktor kualitas pengajaran, khususnya kompetensi guru terhadap hasil belajar siswa telah ditunjukkan oleh hasil penelitian. Salah satu diantaranya penelitian Nana Sudjana (1984) di bidang Pendidikan Kependudukan. Hasil penelitian tersebut menunjukkan bahwa 76,6\% hasil belajar siswa dipengaruhi oleh kompetensi guru, dengan rincian kemampuan guru mengajar memberikan sumbangan $32,43 \%$, penguasaan materi pelajaran memberikan sumbangan $32,58 \%$ dan sikap guru terhadap mata pelajaran memberikan sumbangan $8,60 \%$

\section{Hasil Observasi Aktivitas Siswa dalam PBM}

Berdasarkan data pada tabel 4.2 nampak bahwa aktivitas siswa dalam KBM secara keseluruhan dari siklus I ke siklus II mengalami kemajuan. Pada aspek perhatian siswa terhadap penjelasan guru di siklus I terdapat 57,69 \% dan di siklus II terdapat 92,30\%. Terdapat $61.53 \%$ siswa yang aktif memberi jawaban atau tanggapan terhadap soal-soal materi di siklus I, dan di siklus II menjadi $100 \%$. Terdapat 57,69\% siswa yang merangkum materi pelajaran yang, di siklus II menjadi 76,92\%. Hal ini dikarenakan pada siklus I siswa masih disibukkan dengan keingintahuan terhadap pemakaian media ini. Perhatian siswa terfokus pada media yang akan dipakai dalam pembelajaran, sehingga siswa kurang memperhatikan penjelasan yang diberikan guru. Hal ini masih terbawa saat kegiatan berlangsung, masih ada beberapa siswa yang tidak mau menjawab pertanyaan yang sudah menjadi bagiannya, sehingga harus dijawab oleh teman yang lain. Tetapi di siklus II siswa sudah mulai terbiasa dengan kegiatan tersebut dan mulai menyadari pentingnya penjelasan guru sebelum kegiatan, juga mulai berani untuk memberikan jawaban ataupun tanggapan terhadap pertanyaan-pertanyaan yang disajikan dalam 
pembelajaran menggunakan beberan charta dan merasa perlu juga untuk membuat rangkuman materi pelajaran yang didiskusikan.

Selain itu terdapat juga beberapa siswa yang beraperilaku tidak relevan dalam PBM, pada siklus I terdapat 6 siswa, hal tersebut dapat diatasi oleh guru dengan cara selalu menunjuk siswa-siswa tersebut untuk memberikan tanggapan terhadap pertanyaan yang sudah dijawab oleh temannya. Sehingga siswa tersebut akan berusaha untuk selalu aktif dan perilaku siswa tersebut tidak terulang pada siklus II. Tetapi pada siklus II masih terdapat 1 siswa yang masih berperilaku tidak relevan. Siswa tersebut mengikuti kegiatan pembelajaran tetapi kurang perhatian. Menurut catatan peneliti sehari-hari dalam KBM siswa tersebut memang selalu bermasalah.

Dengan media ini kami berupaya untuk membangkitkan motivasi, minat dan perhatian siswa dalam pembelajaran dengan mengubah sikap siswa yang semula pasif untuk menjadi aktif, sehingga nampak perilaku siswa yang belajar dengan penuh semangat, ceria dan menyenangkan. Menurut musfiqon (2012:8), hasil belajar siswa dipengaruhi oleh dua faktor utama, yakni faktor dari dalam diri siswa (internal faktor) dan faktor yang datang dari luar diri siswa (external factor). Faktor dari dalam diri siswa terutama menyangkut kemampuan yang dimiliki siswa. Faktor ini besar sekali pengaruhnya terhadap hasil belajar yang akan dicapai. Berkaitan dengan faktor dari dalaam diri siswa, selain faktor kemampuan, ada juga faktor lain yaitu motivasi, minat, perhatian, sikap, kebiasaan belajar, ketekunan, kondisi sosial ekonomi, kondisi fisik dan psikis.

\section{Hasil Belajar Siswa Tentang Pemahaman dan Penguasaan Konsep}

Berdasar tabel 4.3 menunjukkan bahwa hasil tes pemahaman terhadap materi pelajaran pada siklus I hanya mencapai $61,54 \%$ yang memperoleh nilai di atas KKM, yaitu 65 . Ini berarti indikator keberhasilan siswa (penelitian) belum tercapai. Hal ini kemungkinan disebabkan siswa masih beradaptasi terhadap pembelajaran dengan media ini, sehingga masih agak kesulitan dalam memahami materi pelajaran, mereka masih disibukkan dengan asyiknya bermain yaitu memainkan kartu-kartu di atas beberan charta. Selain itu juga pada siklus ini kelompok belajarnya terlalu besar, sehingga dengan anggota kelompok yang terlalu banyak mengurangi konsentrasi siswa dalam memahami materi pelajaran.

Pada siklus II, pencapaian hasil belajar tentang pemahaman terhadap materi pelajaran mengalami peningkatan, yaitu mencapai $80.77 \%$ siswa memperoleh nilai di atas 65 , yang berarti indikator keberhasilan siswa terhadap materi pelajaran bisa tercapai. Berdasarkan uraian tersebut, maka dapat dinyatakan bahwa "pembelajaran dengan menggunakan media charta sebagai beberan dapat meningkatkan motivasi yang kemudian meningkat pula pada pemahaman hasil belajar siswa kelas VIII-C SMP Negeri 2 Baureno Bojonegoro ”.

Menurut Prosser (1999:11), pembelajaran yang baik adalah pembelajaran yang membawa anak didik pada pemahaman. Hal ini didukung dengan data pada tabel 4.4 tentang respon siswa terhadap KBM yang diambil melalui pembagian angket kepada siswa. Dari data tersebut tampak bahwa pada siklus I maupun siklus II sebagian besar siswa menyatakan pembelajaran dengan media ini sangat menyenangkan dan merupakan hal yang baru sehingga meningkatkan motivasi mereka untuk lebih aktif dalam belajar. Sebagian besar siswa juga menyatakan dengan media pembelajaran ini lebih mudah memahami materi pelajaran, sehingga mereka menginginkan media ini digunakan juga dalam pembelajaran untuk materi-materi berikutnya.

Angkowo dan Kosashi (2007:7) berpendapat bahwa salah satu fungsi media pembelajaran adalah sebagai alat bantu pembelajaran yang ikut mempengaruhi situasi, kondisi dan lingkungan belajar dalam rangka mencapai tujuan pembelajaran yang telah diciptakan dan didesain oleh guru. Selain itu media dapat memperjelas pesan agar tidak terlalu bersifat verbal (dalam bentuk kata tertulis dan kata lisan belaka). Memanfaatkan media secara tepat dan bervariasi akan dapat mengurangi sikap pasif siswa. 


\section{KESIMPULAN}

Berdasarkan pengamatan dan analisis data, pada siklus pertama penggunaan charta sebagai beberan simulasi dalam pembelajaran masih kurang efektif dan efisien pelaksanaannya, karena siswa masih kurang memahami peraturan dalam penggunaan media., selain itu jumlah anggota kelompok belajar terlalu banyak. Pada siklus kedua, setelah dilakukan pembimbingan lebih intensif dan penataan kembali kelompok belajar, dari 2 kelompok menjadi 4 kelompok, pelaksanaan kegiatan belajar mengajar lebih efektif dan efisien, siswa aktif dan perhatian, suasana belajar tampak kondusif dan menyenangkan.

Berdasarkan hasil penelitian ini dapat disimpulkan, bahwa penggunaan media charta sebagai beberan dalam pembelajaran dapat meningkatkan motivasi belajar siswa yang akhirnya dapat juga meningkatkan pemahaman siswa pada mata pelajaran IPA di kelas VIII-C SMP Negeri 2 Baureno Bojonegoro. Berdasarkan hasil survei respon siswa terhadap pembelajaran, media ini perlu dilanjutkan dan diterapkan pada pembelajaran berikutnya pada materi yang sama dan perlu dicobakan pada materi yang lain

\section{DAFTAR PUSTAKA}

Angkowo R dan A. Kosasih. 2007. Optimalisasi Media Pembelajaran.Jakarta, PT. Grasindo Musfiqon. 2012. Pengembangan Media dan Sumber Pembelajaran. Jakarta: PT Prestasi Pustakaraya

Prosser, Michael and Keith Trigwell. 1999. Understanding Learning and Teaching. Philadelphia: Open University.

Pusat Kurikulum. 2002. Kurikulum dan Hasil Belajar, Kompetensi Dasar Mata Pelajaran Biologi Sekolah Menengah Pertama dan Madrasah Tsanawiyah. Balai Penelitian dan Pengembangan, Departemen Pendidikan Nasional

Sabri, Ahmad. 2005. Strategi Belajar Mengajar dan Micro Teaching. Jakarta, Quantum Teaching

Winkel, 1984. Psikologi Pendidikan dan Evaluasi Belajar. Jakarta: Gramedia 